\title{
The Influence of Soft and Hard Quality Management Practices on Organizational Performance at The Vocational High Schools
}

\author{
Giri Wiyono \\ Electrical Education \\ Engineering Faculty, Yogyakarta State University \\ giriwiyono@uny.ac.id
}

\begin{abstract}
The aim of this research was to examine the influence of soft quality management and hard quality management on organizational performance at the Vocational High Schools. The research proposed several hypotheses relating to the influence between soft quality management factors, hard quality management factors, and organizational performance at the Vocational High Schools. The type of research was expostfacto by the survey method. This research was carried out at the Vocational High Schools located in Yogyakarta Special Region, covering Yogyakarta, Sleman, Bantul, Kulonprogo, and Gunungkidul. This research used a sample of 139 the Vocational High Schools. Subjects were the managers staffs at the Vocational High Schools including the principal, deputy principal, and head of department at the Vocational High Schools. Data were collected by using questionnaires. The test for validity and reliability of research instruments was used the total item correlation and Alpha Croncbach coefficient. While for testing the validity and reliability of the indicators was done through confirmatory factor analysis. This research used structural equation modeling (SEM) analysis. The findings showed that soft quality management factors had a positive, direct, and significant effect on organizational performance at the Vocational High Schools; hard quality management factors had a positive, direct, and significant effect on organizational performance at the Vocational High Schools.
\end{abstract}

Keywords-soft quality management; hard quality management; organizational performance; Vocational High School.

\section{INTRODUCTION}

The Quality Management (QM) is a part of the Total Quality Management (TQM). In the context of education, Quality Management (QM) a new thing. Sallis (2002:27) defines the concept of TQM in education as follows: "TQM is a philosophy of continuous improvement, which can provide any educational institution with a set of practical tools for meeting and exceeding present and future customers needs, wants, and expectations". Thus, QM is a philosophy about education improvement in school that is done continuously by using a set of principles for managing the school organization.

In connection with the implementation of QM, [1] states that the application of QM in education is done in the form of the application of the TQM principles. Even Weller in the [2] concluded that the application of TQM principles shows the positive results, so that schools adopt TQM as the process of reconstruction of education in schools.

According to the standard ISO 9001:2000, there are eight principles of the quality management system, namely: focus on the customer, leadership, the involvement of all people, process approach, system approach, continual improvement, the fact approach to decision-making, and mutual beneficial customers relationship (Point Development International, 2008:4). Therefore, the eight main principles of the quality management system become a standard in the application of QM in schools.

Reference [3] say that. implementation of QM contains two aspects, namely hard quality management, and soft quality management. Hard quality management is related to the production orientation and emphasis on systems, data collection, and measurement. Meanwhile, soft quality management is related to human resource management in organizations including commitment, cooperation, involvement, training, and so on. In this study, soft quality management has four dimensions, namely: (1) leadership, (2) focus on the customer, (3) the involvement of all people, and (4) mutual beneficial customer relationship. Meanwhile, the hard quality management has four dimensions, namely:(1) the process approach, (2) system approach, (3) continuous improvement, and (4) the fact approach to decision-making.

Currently the management of education in Indonesia has implemented the school-based management (SBM). In implementing SBM in Vocational High Schools are carried out by developing the Quality Management System of ISO 9001:2000 (ISO 9001:2008) standard (Directorate General of Primary and Secondary Education- Ministry of National Education, 2009: 128-134). The TQM is the foundation of quality management system of ISO 9001 standard. Thus, the vocational high schools in Indonesia, which have the certification of the Quality Management System of ISO 9001:2008 standard, have implemented QM in management education to compete globally.

School performance can be measured from inputs, processes, outputs, outcomes, productivity, efficiency, and effectiveness (Slamet PH., 2004:8). These measures serve as 
benchmarks to assess the performance of the school organization.

The implementation of the principles of quality management is urgent for Vocational High Schools that wish to improve their school performance. Therefore, this research is important to deeply investigate the effect of the application of total quality management, both soft quality management and hard quality management, to increase organizational performance in Vocational High Schools. The results of this research will provide a constructive recommendations to improve organizational performance in Vocational High Schools which apply the principles of the quality management system of ISO 9001 standard, so that this has an impact on improving the quality of Vocational High Schools.

\section{METHOD}

This research used an analysis unit of school organization. The population in this research was all public and private Vocational High Schools in Yogyakarta Special Region which have gained the certification of Quality Management System ISO 9001:2000/ISO 9001:2008 standard or are currently in the process of certification. The samples in this research consisted of 139 vocational high schools. Subjects were the managerial staffs at the Vocational High Schools including the principals, deputy principals, and heads of department. In this research, there are two exogenous latent variables, namely: soft quality management $\left(\xi_{1}\right)$, and hard quality management $\left(\xi_{2}\right)$, as well as the endogenous latent variables, namely the performance of the organization $\left(\eta_{1}\right)$.

In this research, the test for the validity and reliability of the indicators of constructs was done through a measurement model with Confirmatory Factor Analysis (CFA). This research used the Structural Equation Modeling (SEM) with Lisrel 8.70 program.

The hypotheses in this research were that: (1) there is a positive effect of the soft quality management on organizational performance in Vocational High Schools, and (2) there is a positive effect of the hard quality management on organizational performance in Vocational High Schools.

\section{RESULTS AND DISCUSSION}

\section{A. Latent Variable Measurement Model}

This study uses the second order confirmatory factor analysis (CFA). Measurements on the second order CFA shows the relationship between the indicators and the latent variables (constructs). The results of testing using the second order CFA for measuring the organizational performance construct (KINOR)

The test results of the second order CFA of organizational performance construct (KINOR) produces the goodness of fit index for $\mathrm{p}$-value is 0,06836 and RMSEA is 0,036 . This measurement model is fit after a modification of the model by freeing parameters of the indicators of organizational performance construct, so that parameters correlate with each other. Thus, this measurement model meets the statistical requirements and it is categorized as a measurement model that fits to measure the construct of organizational performance. The results of testing the second order CFA are shown in the following Table 1.

TABLE I. THE TEST RESULTS OF THE ORGANIZATIONAL PERFORMANCE CONSTRUCT

\begin{tabular}{|l|c|c|c|c|c|}
\hline Dimension & $\begin{array}{c}\text { Standardized } \\
\text { Factor Loading }\end{array}$ & $\begin{array}{c}\text { Standard } \\
\text { Error }\end{array}$ & $\mathbf{t}_{\text {value }}$ & $\mathbf{R}^{\mathbf{2}}$ & Comment \\
\hline KINOR-1 & 0,87 & 0,07 & 9,30 & 0,76 & significant \\
\hline KINOR-2 & 0,87 & 0,07 & 9,87 & 0,76 & significant \\
\hline KINOR-3 & 0,84 & 0,07 & 10,98 & 0,71 & significant \\
\hline KINOR-4 & 0,90 & 0,07 & 9,88 & 0,82 & significant \\
\hline KINOR-5 & 1,00 & 0,07 & 12,98 & 1,01 & significant \\
\hline KINOR-6 & 0,96 & 0,07 & 9,99 & 0,92 & significant \\
\hline \multicolumn{7}{|c|}{ Construct Reliability (CR) } & $\mathbf{0 , 8 2}$ & good \\
\hline
\end{tabular}

Source: Result of LISREL Analysis

From Table 1, it can be concluded that the organizational performance construct produces six significant dimensions and coefficient values of standardized factor loading which over 0,50 with a $t$-value greater than 1,96 . Meanwhile, the coefficient of construct reliability for organizational performance construct is greater than 0,70 . This means that the indicators and dimensions used to measure organizational performance construct have adequate validity and reliability.

The test results of the second order CFA of soft quality management construct (Soft QM) produces $\mathrm{p}_{\text {-value }}=0,08019$ $\left(\mathrm{p}_{\text {-value }}>0,05\right)$ and RMSEA $=0,047$ (RMSEA $\left.<0,05\right)$. This measurement model is fit after a modification of the model by freeing parameters of the indicators of soft quality management construct, so that parameters correlate with each other.

Thus, this measurement model meets the statistical requirements and it is categorized as a measurement model that fit to measure the construct of soft quality management. The results of testing the second order CFA are shown in the following Table 2.

TABLE II. THE TEST RESULTS OF SECOND ORDER CFA SOFT QUALITY MANAGEMENT CONSTRUCT

\begin{tabular}{|l|c|c|c|c|c|}
\hline Dimension & $\begin{array}{c}\text { Standardized } \\
\text { Factor Loading }\end{array}$ & $\begin{array}{c}\text { Standard } \\
\text { Error }\end{array}$ & $\mathbf{t}_{\text {value }}$ & $\mathbf{R}^{\mathbf{2}}$ & Comment \\
\hline MANMU-1 & 0,85 & 0,07 & 11,03 & 0,72 & significant \\
\hline MANMU-2 & 0,92 & 0,07 & 11,34 & 0,85 & significant \\
\hline MANMU-3 & 0,89 & 0,07 & 11,62 & 0,79 & significant \\
\hline MANMU-4 & 0,89 & 0,07 & 10,58 & 0,78 & significant \\
\hline \multicolumn{7}{|c|}{ Construct Reliability (CR) } & $\mathbf{0 , 7 8}$ & good \\
\hline
\end{tabular}

Source: Result of LISREL Analysis

From Table 2, it can be concluded that the soft quality management construct produces four significant dimensions and coefficient values of standardized factor loading has over 0,50 with a t-value greater than 1,96 . Meanwhile, the coefficient of construct reliability for a soft quality management construct is greater than 0,70. This means that the indicators and dimensions used to measure the soft quality management construct have adequate validity and reliability. 
The test results of the second order CFA of hard quality management construct (Hard $\mathrm{QM})$ produces $\mathrm{p}$-value $=0,07198$ $(\mathrm{p}$-value $>0,05)$ and RMSEA $=0,047 \quad(\mathrm{RMSEA}<0,05)$. This measurement model is fit after a modification of the model by freeing parameters of the indicators of hard quality management construct, so that parameters correlate with each other.

Thus, this measurement model meets the statistical requirements and it is categorized as a measurement model that fit to measure the construct of hard quality management. The results of testing the second order CFA are shown in the following Table 3 .

TABLE III. THE TEST RESULTS OF SECOND ORDER CFA HARD

\begin{tabular}{|l|c|c|c|c|c|}
\multicolumn{7}{c|}{ QUALITY MANAGEMENT CONSTRUCT } \\
\hline Dimension & $\begin{array}{c}\text { Standardized } \\
\text { Factor Loading }\end{array}$ & $\begin{array}{c}\text { Standard } \\
\text { Error }\end{array}$ & $\mathrm{t}_{\text {value }}$ & $\mathrm{R}^{2}$ & Comment \\
\hline MANMU-5 & 0,97 & 0,07 & 10,91 & 0,95 & significant \\
\hline MANMU-6 & 0,94 & 0,07 & 11,33 & 0,88 & significant \\
\hline MANMU-7 & 0,93 & 0,07 & 11,06 & 0,87 & significant \\
\hline MANMU-8 & 0,92 & 0,07 & 11,08 & 0,85 & significant \\
\hline \multicolumn{7}{|c|}{ Construct Reliability (CR) } & $\mathbf{0 , 8 8}$ & good \\
\hline
\end{tabular}

Source: Result of LISREL Analysis

From table 3 , it can conclude that the hard quality management construct produces four significant dimensions and coefficient values of standardized factor loading has over 0,50 with a $t$-value greater than 1,96 . Meanwhile, the coefficient of construct reliability for a hard quality management construct is greater than 0,70 . This means that the indicators and dimensions used to measure the hard quality management construct have adequate validity and reliability.

Thus, it can be concluded that the indicators and dimensions used to measure the constructs of organizational performance, soft quality management, and hard quality management have adequate validity and reliability.

\section{B. The Structural Model of Latent Variable Relationships}

The results of structural model testing is obtained the model of causal relationships between two exogenous latent variables (soft quality management, and hard quality management) with one endogenous latent variable (organizational performance) which is shown within path diagram in Fig. 1.

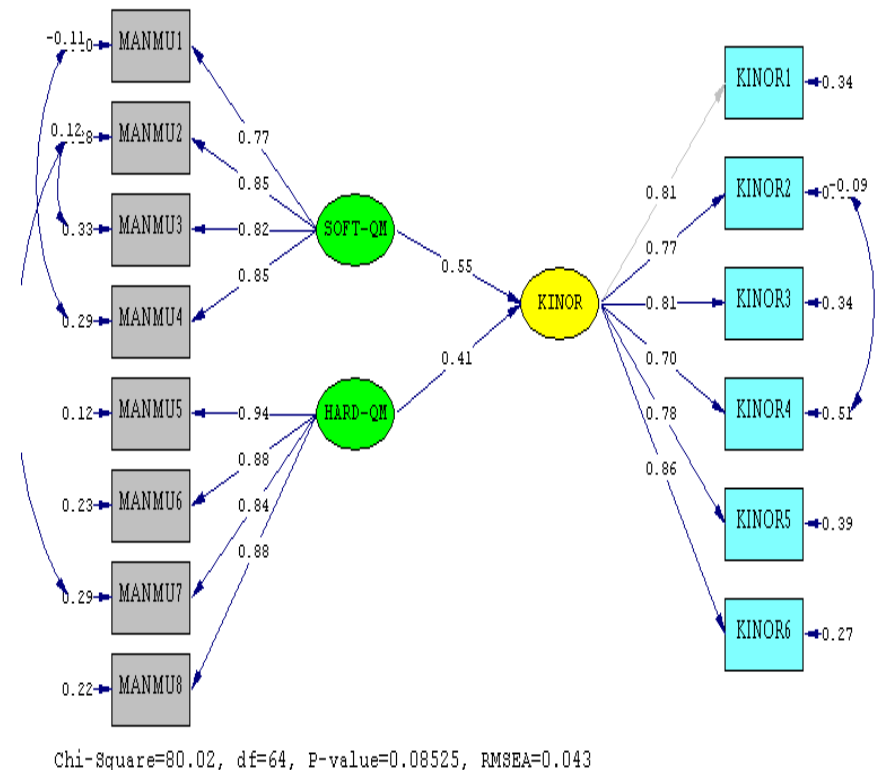

Fig 1. The Results of the Structural Model Testing Spurce: Result of LISREL Analysis

The results of the standardized structural equation model analysis is obtained 7 values that meet goodness of fit index criteria. This results are shown in the following Table 4.

TABLE IV. THE RESULTS OF THE STRUCTURAL MODEL ANALYSIS

\begin{tabular}{|c|c|c|c|}
\hline $\begin{array}{c}\text { Goodness of fit } \\
\text { index criteria }\end{array}$ & $\begin{array}{c}\text { Cutoff } \\
\text { value }\end{array}$ & $\begin{array}{c}\text { Computation } \\
\text { results }\end{array}$ & Comment \\
\hline P-value & $>0,05$ & 0,08525 & good fit \\
\hline RMSEA & $\leq 0,05$ & 0,043 & good fit \\
\hline RMR & $<0,05$ & 0,030 & good fit \\
\hline GFI & $\geq 0,90$ & 0,92 & good fit \\
\hline NNFI & $\geq 0,90$ & 0,99 & good fit \\
\hline NFI & $\geq 0,90$ & 0,98 & good fit \\
\hline RFI & $\geq 0,90$ & 0,98 & good fit \\
\hline
\end{tabular}

Source: Result of LISREL Analysis

From Table 4, it can conclude that the structural model meets some criterias in testing of the model fit and it is categorized as a model that fit to the data. The test results of the structural equation model are obtained the parameters of estimated Lambda-X $\left(\lambda_{\mathrm{x}}\right)$ as standardized factor loading coefficients that are shown in the following Table 5.

TABLE V. THE RESULTS OF ESTIMATED LAMBDA-X PARAMETER

\begin{tabular}{|c|c|c|c|c|c|}
\hline $\begin{array}{c}\text { Measure- } \\
\text { ment model }\end{array}$ & $\begin{array}{l}\text { Standard-iz } \\
\text { factor loadi }\end{array}$ & $\mathbf{t}_{\text {value }}$ & $\begin{array}{c}\text { Error } \\
\text { var }\end{array}$ & $\mathbf{R}^{2}$ & Comment \\
\hline $\mathrm{X}_{1} \leftarrow \xi_{1}$ & 0,77 & 10,53 & 0,07 & 0,60 & Significant \\
\hline $\mathrm{X}_{2} \leftarrow \xi_{1}$ & 0,85 & 12,23 & 0,07 & 0,72 & Significant \\
\hline $\mathrm{X}_{3} \leftarrow \xi_{1}$ & 0,82 & 11,50 & 0,07 & 0,67 & Significant \\
\hline $\mathrm{X}_{4} \leftarrow \xi_{1}$ & 0,85 & 12,07 & 0,07 & 0,71 & Significant \\
\hline $\mathrm{X}_{5} \leftarrow \xi_{2}$ & 0,94 & 14,62 & 0,06 & 0,88 & Significant \\
\hline $\mathrm{X}_{6} \leftarrow \xi_{2}$ & 0,88 & 13,01 & 0,07 & 0,77 & Significant \\
\hline $\mathrm{X}_{7} \leftarrow \xi_{2}$ & 0,84 & 12,20 & 0,07 & 0,71 & Significant \\
\hline $\mathrm{X}_{8} \leftarrow \xi_{2}$ & 0,88 & 13,10 & 0,07 & 0,78 & Significant \\
\hline
\end{tabular}

Source: Result of LISREL Analysis 
From Table 5, it can conclude that t-test values of all observed variables of soft quality management $\left(\mathrm{X}_{1}-\mathrm{X}_{4}\right)$ and hard quality management $\left(\mathrm{X}_{5}-\mathrm{X}_{8}\right)$ are greater than $1,96(\mathrm{t}-$ test $>1,96$ ), so that they can be declared significant. Besides, the values of the standardized factor loading coefficient $\left(\lambda_{x}\right)$ have over above 0,50 so that they can be categorized as good. This means that the observed variables can be used to measure significantly the latent variables of soft quality management and hard quality management.

The test results of the structural equation model are obtained the parameters of estimated Lambda-Y $\left(\lambda_{y}\right)$ as standardized factor loading coefficients that are shown in the following Table 6 .

TABLE VI. THE RESULTS OF ESTIMATED LAMBDA-Y PARAMETER

\begin{tabular}{|c|c|c|c|c|c|}
\hline $\begin{array}{c}\text { Measurement } \\
\text { model }\end{array}$ & $\begin{array}{c}\text { Standardized } \\
\text { factor loading }\end{array}$ & $\mathbf{t}_{\text {value }}$ & $\begin{array}{c}\text { Error } \\
\text { var }\end{array}$ & $\mathbf{R}^{2}$ & Comment \\
\hline $\mathrm{Y}_{1} \leftarrow \eta_{1}$ & 0,81 & -- & --- & 0,66 & Significant \\
\hline $\mathrm{Y}_{2} \leftarrow \eta_{1}$ & 0,77 & 10,37 & 0,09 & 0,60 & Significant \\
\hline $\mathrm{Y}_{3} \leftarrow \eta_{1}$ & 0,81 & 11,18 & 0,09 & 0,66 & Significant \\
\hline $\mathrm{Y}_{4} \leftarrow \eta_{1}$ & 0,70 & 9,06 & 0,09 & 0,49 & Significant \\
\hline $\mathrm{Y}_{5} \leftarrow \eta_{2}$ & 0,78 & 10,61 & 0,09 & 0,61 & Significant \\
\hline $\mathrm{Y}_{6} \leftarrow \eta_{2}$ & 0,86 & 12,07 & 0,09 & 0,73 & Significant \\
\hline
\end{tabular}

Source: Result of LISREL Analysis

From Table 6 , it can conclude that $t_{\text {-test }}$ values of all observed variables of organizational performance $\left(\mathrm{Y}_{1}-\mathrm{Y}_{6}\right)$ are greater than $1,96\left(\mathrm{t}_{\text {-test }}>1,96\right)$, so that they can be declared significant. Besides, the values of the standardized factor loading coefficient $\left(\lambda_{y}\right)$ have over above 0,50 so that they can be categorized as good. This means that the observed variables can be used to measure significantly the latent variables of organizational performance.

The results of the hypotheses testing are obtained the gamma parameters $(\gamma)$ as the direct effect of soft quality management, and hard quality management latent variables on organizational performance latent variables that are shown in the following Table 7.

TABLE VII. THE TESTING RESULTS OF PARAMETER GAMMA ( $)$
\begin{tabular}{|c|c|c|}
\hline GAMMA & & \\
\hline & SOFT-QM & HARD-QM \\
\hline KINOR & $\mathbf{0 , 4 4}$ & $\mathbf{0 , 3 3}$ \\
& $\mathbf{( 0 , 1 6 )}$ & $\mathbf{( 0 , 1 6 )}$ \\
& $\mathbf{2 , 7 1}$ & $\mathbf{2 , 0 4}$ \\
\hline
\end{tabular}
Source: Result of LISREL Analysis

From Table 7, the results of the hypotheses testing produces the value of the path coefficient $\left(\gamma_{1}\right)=0,44$ with the value of the $t$-value $=2,71$ and the value of path coefficient $\left(\gamma_{2}\right)$ $=0,33$ with the value of the $t_{- \text {value }}=2,04$. This results show that the t-test value for two paths coefficient values are greater than 1,96 ( $\left.\mathrm{t}_{\text {-test }}>1,96\right)$. Thus, this results can be concluded that both the path coefficients are significant, so that this research hypotheses have proved.

It can be concluded that this research hypotheses have been proven, namely: (1) there is a positive effect of the soft quality management on organizational performance in Vocational High Schools, and (2) there is a positive effect of the hard quality management on organizational performance in Vocational High Schools. The results of this research also concluded that the magnitude of the effect of the soft quality management on the organizational performance is 0,44 or $(0,44)^{2}$ by $19,36 \%$; and the effect of the hard quality management on the organizational performance is 0,33 or $(0,33)^{2}$ by $10,89 \%$. Meanwhile, the magnitude of the effect of the soft quality management and hard quality management together on the organizational performance is 0,88 or $88 \%$. This provides a common fact that the soft quality management and hard quality management provide a major influence on organizational performance improvement at the Vocational High Schools in DIY .

\section{CONCLUSION}

The results of this research can be summarized as follows: (1) the soft quality management has positive effect on organizational performance in Vocational High Schools, and (2) the hard quality management has positive effect on organizational performance in Vocational High Schools. These results imply that the level of quality of the organizational performance in Vocational High Schools influenced strongly by the quality of soft quality management, and hard quality management. Thus, improving the quality management can affect on improving the quality of organizational performance in Vocational High Schools. This will certainly have an impact on improving the quality of vocational education in DIY.

\section{REFERENCES}

[1] Fields, Joseph C., Total Quality for schools, a Guide for Implementation. Wiscounsin: ASQC Quality Press, 1994.

[2] West-Burnham, Understanding Quality, dalam "The Principles and Practice of Educational Management”. England: Pearson Education Ltd., 1998.

[3] Wilkinson, Adrian, et al., Managing with Total Quality Management, Theory and Practice. London: MacMillan Press Ltd., 1998.

[4] Joreskog, Karl \& Dag Sorbom, Lisrel 8: User's Reference Guide. Chicago: Scientific Software International, 1996.

[5] Sallis, Edward, Total Quality Management in Education Third Edition. London: Kogan Page Ltd., 2002.

[6] Setyo Hari Wijanto, Structural Equation Modeling with LISREL 8.8: Concepts, and Tutorial. Yogyakarta: Graha Ilmu, 2008. 